\title{
Upaya Membangun Demokrasi \\ Melalui Penyelesaian \\ Pelanggaran Hak Asasi Manusia
}

\author{
Trisno Raharjo
}

\section{Abstract}

There is a mutual relationship between democracy building and human rights respecting.

\section{Pendahuluan}

Negara-negara dalam masa transisi dari penguasa otoriter ke demokrasi, tidak dapat mengelakkan dan menghindari kebutuhan untuk menanggapi pelanggaran Hak Asasi Manusia (HAM) di masa lampau. Indonesia merupakan salah satu negara dengan begitu banyak kasus pelanggaran HAM yang belum tuntas dalam penyelesaiannya, sehingga terkesan tidak memenuhi rasa keadilan yang diharapkan masyarakat, terutama dari pihak korban. Mulai dari kasus-kasus yang sudah jelas memiliki banyak bukti hukum maupun yang telah berkurang atau tidak lagi memiliki bukti hukum yang kuat, seperti Kasus Semanggi I dan II, Kasus Tanjung Priok, Kasus Tengku Bantaqiah. Keadaan ini menggambarkan betapa Indonesia belum dapat menyediakan cara-cara yang dapat memberikan keadilan yang didambakan oleh pihak korban maupun keluarga korban serta masyarakat pada umumnya.

Dengan demikian, tantangan yang dihadapi bangsa Indonesia yang sedang mengalami masa transisi dari sistem represif ke suatu sistem negara yang mengembangkan prinsip-prinsip demokrasi saat ini ialah bagaimana memenuhi tuntutan untuk dapat secara tegas menghadapi mereka yang berpartisipasi di dalam, atau yang dinilai telah mengambil keuntungan dari sistem pemerintahan yang represif di masa lalu. Untuk memenuhi tuntutan tersebut perlu diperhatikan bahwa ada usaha yang jelas dari pemerintah yang baru dalam memutuskan rantai rezim lama dengan pemerintahan baru. ${ }^{1}$ Salah satu bentuknya adalah penegakan hukum.

'Komisi Nasional Hak Asasi Manusia. 2001. Keadilan dalam Masa Transisi. Jakarta: KOMNASHAM. HIm. 5. 
khususnya yang berhubungan dengan pelanggaran HAM. Bagaimana bentuk penegakan hukum terhadap pelanggaran HAM berat di masa lalu dan bagaimana dampaknya terhadap pengembangan demokratisasi di Indonesia?

\section{Perkembangan HAM}

HAM adalah hak-hak yang dimiliki oleh setiap manusia dan berhak dinikmati sematamata karena ia adalah manusia. Pada Konperensi Dunia tentang HAM 1993, berbagai pemerintah menegaskan dalam Deklarasi Wina bahwa HAM adalah hak yang dibawa oleh semua manusia sejak lahir dan bahwa perlindungan atas hak itu merupakan tanggung jawab pertama pemerintah. HAM didasarkan pada prinsip dasar bahwa semua orang mempunyai martabat kemanusiaan hakiki, tanpa memandang jenis kelamin, ras, warna kulit, bahasa, asal-usul kebangsaan, umur, kelas, agama atau keyakinan politik, setiap manusia berhak untuk menikmati hak mereka. $^{2}$

Standar HAM internasional telah ditetapkan sejak 1948 dalam Deklarasi Semesta Hak Asasi Manusia Perserikatan Bangsa-Bangsa (PBB) atau United Nations Universal Declaration of Human Rights yang dikodifikasikan pada 1966 dalam Kesepakatan Internasional Hak Sipil dan Politik (International Convenant on Civil and Political Rights) serta Kesepakatan Internasional Hak Ekonomi, Sosial, dan Budaya (International Convenant on Economic, Social and Cultural Rights).

HAM dalam Kesepakatan 1966 dibagi menjadi dua kelompok utama, yaitu: hak sipil dan politik atau International Convenant on Civil and Political Rights (ICCPR) dan hak ekonomi, sosial, dan budaya atau International Convenant on Economic. Social and Cultural Rights (ICESCR). ${ }^{3}$ Hak sipil dan politik mencakup semua hak yang melindungi individu terhadap pelanggaran-pelanggaran keamanan fisik dengan eksekusi sewenangwenang, penyiksaan, dan perlakuan atau hukuman yang kejam, merendahkan atau tidak manusiawi. Hak sipil dan politik juga melindungi warga negara terhadap penganiayaan oleh pejabat negara melalui pengakuan di depan hukum, prasangka tak bersalah, jaminan pengadilan terbuka yang adil dan tidak memihak, pelarangan undangundang berlaku surut ke belakang, dan perlindungan terhadap penangkapan. penahanan sewenang-wenang atau pembuangan ke luar negeri. Hak atas kewarganegaraan dan memiliki rumah di

${ }^{2}$ Margaret A. Schuler dan Dorothy Q. Thomas, Penyunting. 2001. Hak Asasi Manusia Kaum Perempuan: Langkah demi Langkah. Jakarta: LBH APIK. HIm. 12.

${ }^{3}$ Pembagian ini didorong oleh pertimbangan politik dan mencerminkan kompromi antara negara dengan perekonomian yang 'berorientasi pasar' atau. 'kapitalis' yang cenderung memberi penekanan pada hak sipil dan politik, dan negara dengan perekonomian 'terencana' atau 'sosialis' yang cenderung untuk memberi penekanan pada hak-hak ekonomi dan sosial. 
suatu negara juga dilindungi oleh hak atas kebangsaan, kebebasan bergerak, dan memilih tempat tinggal. ${ }^{4}$

Landasan dan arti penting Konvenan Hak Sipil dan Politik dinyatakan dalam paragraf pertama mukadimah: "Sesuai dengan prinsipprinsip yang dinyatakan dalam Piagam PBB, pengakuan atas martabat yang melekat dan hak-hak yang sama dan tidak dapat dicabut dari semua anggota umat manusia merupakan landasan kebebasan, keadilan, dan perdamaian dunia." Konvenan ini merupakan hak hukum, bukan sekedar dalil moral yang tidak memiliki kewajiban hukum. Hak ini bersifat universal, karena didasarkan pada pengakuan atas kesamaan umat manusia tanpa perbedaan, serta merupakan hak internasional dan menjadi dasar struktur perdamaian dunia. ${ }^{5}$

Saat ini Konvenan Internasional Hak Sipil dan Politik telah diratifikasi oleh 141 negara atau telah mencapai $95 \%$ dari negara-negara anggota PBB yang berjumlah 159 negara. ${ }^{6}$ Kovenan Hak Sipil dan Politik pada dasarnya memuat ketentuan mengenai pembatasan penggunaan kewenangan oleh aparat represif negara, umumnya hak-hak yang terhimpun didalamnya juga sering disebut sebagai hakhak negatif (negative rights). Artinya, hak-hak dan kebebasan yang dijamin didalamnya akan dapat terpenuhi, apabila peran negara terbatasi atau terlihat minus. Apabila negara berperan intervensionis, maka tak dapat dielakkan hak-hak dan kebebasan yang diatur didalamnya akan dilanggar oleh negara. ${ }^{7}$

Hak-hak yang terdapat dalam Konvenan Hak Sipil dan Politik dapat diklasifikasikan menjadi dua, yaitu non-derogable dan derogable. Hak-hak dalam non-derogable bersifat absolut yang tidak boleh dikurangi oleh negara walaupun dalam keadaan darurat. Hak-hak yang termasuk ke dalam jenis ini adalah: Hak atas hidup (rights to life); Hak bebas dari penyiksaan (rights to be free from torture); Hak bebas dari perbudakan (rights to be free from slavery); hak bebas dari penahanan karena gagal memenuhi perjanjian (utang); hak bebas dari pemidanaan yang berlaku surut; hak sebagai subjek hukum; dan hak atas kebebasan berpikir, keyakinan dan agama. Apabila pelanggaran terhadap hak non-derogable

'Rhoda E. Howard. 2000. HAM: Penjelajahan Dalil Relativisme Budaya. Jakarta: Grafiti Press. Hilm. 16.

"Vratislav Pechota. 2001. "Konvenan Hak Sipil dan Politik: Sejarah dan Perkembangnnya." Dalam Ifdhal Kasim. Editor. Hak Sipil dan Politik: Esai-esai Pilihan Buku 1. Jakarta: ELSAM. Hlm. 1-2.

oIndonesia belum melakukan ratifikasi terhadap konvenan ini, meskipun disadari bahwa konvenan ini memiliki tingkat universalitas yang tinggi, sehingga dianggap sebagai salah satu The International Bill of Human Rights. Lihat Ifdal Kasim. 2000. "Kata Pengantar Ifdal Kasim" Editor. Hak Sipil dan Politik: Esai-esai Pilihan Buku 1. Jakarta: ELSAM. HIm. $x$-xi. Lihat pula C. de Rover. To Serve \& To Protect: Acuan Universal Penegakan HAM. Jakarta: Rajawali Press. HIm. 55.

'Ifdal Kasim, 2001. "Kata Pengantar Ifdal Kasim" Editor. Hak Sipil dan Politik: Esai-esai Pilihan Buku 1. Jakarta: ELSAM. HIm. x-xi. 
dilakukan oleh negara. maka negara akan dianggap telah melakukan pelanggaran serius $\mathrm{HAM}$ (grosss violation of human rights). ${ }^{8}$

Hak-hak derogable atau hak-hak relatif yakni hak-hak yang boleh dikurangi atau dibatasi pemenuhannya oleh negara. Hak-hak yang termasuk dalam derogable adalah: hak atas kebebasan berkumpul secara damai; hak atas kebebasan berserikat, termasuk membentuk dan menjadi anggota serikat buruh; dan hak atas kebebasan menyatakan pendapat atau berekspresi, termasuk kebebasan mencari, menerima dan memberikan informasi dan segala macam gagasan tanpa memperhatikan batas. Negara tidak dapat mengurangi begitu saja hak derogable, pembatasan tersebut tidak boleh melebihi dari yang ditetapkan Konvenan Hak Sipil dan Politik. Disamping itu, negara yang melakukan pengurangan hak tersebut diwajibkan menyampaikan alasan-alasan mengapa pembatasan dilakukan kepada semua anggota negara yang telah meratifikasi Konvenan Hak Sipil dan Politik. ${ }^{9}$

Ketentuan Reservasi ${ }^{10}$ sebagaimana dimaksud Konvenan Hak Sipil dan Politik tunduk pada ketentuan Konvensi Wina tentang Perjanjian Internasional, khususnya Pasal 19 yang menetapkan: Suatu negara dapat... merumuskan suatu reservasi kecuali," Pertama, Reservasi itu dilarang oleh traktat; Kedua, Traktat tersebut menentukan bahwa hanya reservasi-reservasi tertentu yang boleh dibuat, yaitu yang tidak mengecualikan reservasi tersebut; atau Ketiga, Dalam hal yang tidak berada di bawah sub pertama dan kedua, reservasi tidak sesuai dengan objek dan tujuan traktat tersebut.

Disamping The International Bill of $\mathrm{Hu}-$ man Rights, dokumen internasional tentang HAM dapat pula ditemukan dalam bentuk perjanjian internasional, pelbagai standar; model perjanjian, pedoman yang perumusannya dikoordinasikan oleh PBB. Konvensi HAM lainnya adalah Konvensi Eropa tentang HAM, Banjul Charter di Kawasan Afrika, dan Déklarasi HAM di Amerika Latin, serta munculnya deklarasi HAM Organisasi Islam Internasional sesuai dengan Syari'ah Islam atau dikenal sebagai Cairo Declaration. ${ }^{12}$

Pandangan terhadap HAM umumnya dapat dibagi menjadi empat kelompok besar

8/bid. HIm. xii-xiii. Lihat pula Muladi. 1997. Hak Asasi Manusia, Politik dan Sistem Peradilan Pidana. Semarang: BP UNDIP. HIm. xii.

S/bid. HIm. xiil-xiv. Hal ini dapat dicontohkan Pasal 19 ayat (3) menegaskan bahwa restriksi terhadap kebebasan menyatakan pendapat hanya dapat dilakukan berdasarkan undang-undang demi menghormati hak-hak dan reputasi orang lain dan dalam rangka melindungi keamanaan nasional atau ketertiban umum atau kesehatan atau kesusilaan umum.

${ }^{10}$ Reservasi adalah suatu pernyataan sepihak yang dibuat oleh suatu negara ketika menandatanganı. meratifikasi, menerima, menyetujui atau mengaksesi suatu traktat, dengan tujuan untuk mengecualikan atau memodifikasi akibat hukum dari ketentuan-ketentuan tertentu dalam penerapannya.

${ }^{11} \mathrm{C}$. de. Rover, Op. Cit. HIm. 58-59.

${ }^{2}$ Muladi. Op. Cit. HIm. 2. 
yaitu: ${ }^{13}$ Pertama, Pandangan yang menyatakan HAM bersifat universal-absolut. HAM merupakan nilai-nilai universal sebagaimana dirumuskan di dalam The International Bill of Human Rights, dengan tidak memandang profil sosial budaya yang melekat pada masing-masing bangsa. Kedua, Pandangan yang menyatakan HAM bersifat universalrelatif. HAM merupakan nilai-nilai universal, namun terdapat pengecualian yang didasarkan atas asas-asas hukum internasional. Ketiga, Pandangan yang menyatakan HAM bersifat partikularistik-absolut. HAM dipandang sebagai persoalan masing-masing bangsa, tanpa memberikan alasan yang kuat, khususnya dalam melakukan penolakan terhadap berlakunya dokumen-dokumen internasional. Pandangan ini bersifat chauvinis, egois, defensif dan pasif terhadap HAM. Keempat, Pandangan yang menyatakan HAM bersifat partikularistik-relatif. HAM dipandang sebagai masalah universal, namun merupakan másalah nasional masing-masing bangsa. Berlakunya dokumen-dokumen internasional haru's diselaraskan, diserasikan dan diseimbangkan serta memperoleh dukungan dan tertanam dalam budaya bangsa.

\section{HAM dan Negara Demokrasi}

Masalah HAM menjadi agenda penting dan strategis dalam pengembangan demokratisasi. Penghormatan terhadap HAM akan meningkatkan kesadaran demokrasi di kalangan masyarakat sebagai akibat dari mobilitas pendidikan, meningkatnya kehidupan ekonomi serta keterbukaan informasi.

Demokrasi berasal dari istilah Greek Demokratia yang secara harafiah dapat berarti demos atau rakyat dan kratos atau pemerintahan, sehingga secara utuh bermakna pemerintahan oleh rakyat, yang menunjuk pada bentuk-bentuk pemerintahan rakyat yang bersifat partisipatori, baik langsung atau atas dasar perwakilan. ${ }^{14}$

Kriteria demokrasi menurut Juan J. Linz dan Alfred Stepan ${ }^{15}$ adalah "Kebebasan hukum untuk merumuskan dan mendukung alternatifalternatif politik dengan hak yang sesuai untuk bebas berserikat, bebas berbicara, dan kebebasan-kebebasan dasar lain bagi setiap orang; persaingan yang bebas dan anti kekerasan diantara para pemimpin dengan keabsahan periodik untuk memegang pemerintahan; dimasukkannya seluruh jabatan politik yang efektif di dalam proses demokrasi; dan hak untuk berperan serta bagi semua anggota masyarakat politik, apa pun pilihan politik mereka. Secara praktis, hal ini berarti kebebasan untuk mendirikan partaipartai politik dan menyelenggarakan pemilihan umum yang bebas dan jujur dalam jangka waktu tertentu tanpa menyingkirkan jabatan politis efektif apa pun dari akuntabilitas pemilihan yang dilakukan secara langsung maupun tidak langsung."

${ }^{13}$ ibid. HIm. $2 \cdot 4$.

${ }^{14} /$ bid. HIm. 71.

15Juan J. Linz, et. al. 2001. Menjauhi Demokrasi Kaum Penjahat: Belajar dari Kekeliruan NegaraNegara Lain. Jakarta: LIPI. HIm. 26-27. 
Untuk mencapai demokrasi yang terkonsolidasi, otonomi bagi masyarakat sipil dan masyarakat politik dalam kadar yang cukup harus diberikan, serta didukung oleh pemerintahan yang berdasarkan hukum. Dengan suatu hirarki perundang-undangan yang jelas, yang ditafsirkan oleh sistem yudisial yang mandiri, dan didukung oleh budaya hukum yang kuat dalam masyarakat sipil. Sebuah negara hukum sangat dibutuhkan bagi konsolidasi demokrasi. Hal ini merupakan cara yang paling penting yang di dalamnya pemerintah yang terpilih dan administrasi negara tunduk pada jaringan hukum, pengadilan, agen-agen pengontrol serta norma-norma masyarakat sipil yang bukan hanya mengendalikan kecenderungan negara yang tidak sah, melainkan juga menanamkannya di dalam suatu jaringan mekanisme yang saling berkaitan yang membutuhkan keterbukaan dan pertanggungjawaban. ${ }^{16}$

Hubungan antara demokrasi dan hukum. nampak dari batasan bahwa democracy is a political system which supplies regular constitutional opportunities for changing the governing official, and a social mechanism which permit the largest possible part of the population to influence major decision by choosing among contenders for political office. Istilah constitutional menunjukkan bahwa pemerintahan selalu bersifat terbatas. Batas-batas atas praktek pemerintahan berdasarkan hukum tidak hanya berlaku untuk rakyat, tetapi juga untuk pemerintah. ${ }^{17}$
Konsep demokrasi akan mencakup tidak hanya demokrasi politik yang berkaitan dengan pemilihan umum, kepartaian, badan legislatif, tetapi juga demokrasi pembangunan dalam arti luas yang mengatur persamaan kesempatan, pemberdayaan masyarakat, distribusi kesejahteraan, hubungan sipil-militer yang semuanya merupakan the real markers of democracy. Kedua macam bentuk demokrasi tersebut bersifat komplementer untuk merealisasikan hak-hak asasi warga negara baik hak-hak sipil dan politik, hak-hak ekonomi, sosial dan budaya maupun hak untuk berkembang. Kemajuan dalam pèncapaian HAM pada hakikatnya adalah perkembangan demokrasi. $^{18}$

Indonesia sebagai suatu negara yang bergerak menuju demokrasi tentu memerlukan masa transisi. Masa transisi harus dilewati dengan memenuhi syarat-syarat dan sikap-sikap serta kebiasaan-kebiasan yang harus ditanamkan sebelum demokrasi dapat dianggap berhasil dikonsolidasi.

Dari segi perilaku, rezim demokratis dalam sebuah negara terkonsolidasi jika tidak ada tokoh-tokoh nasional; sosial ekonomi, politik utama yang menggunakan sumbersumber penting dalam upaya mencapai tujuan mereka dengan menciptakan rezim non demokratis atau memisahkan diri dari negara. Dari segi sikap, rezim demokratis dapat dikatakan terkonsolidasi jika mayoritas opini publik, bahkan di tengah permasalahan ekonomi yang berat dan ketidakpuasan yang mendalam terhadap pihak yang berwenang,

${ }^{16} /$ bid. HIm. 43-45.

${ }^{17}$ Muladi. Op. Cit. Hlm. 71-72.

${ }^{18} /$ bid. Him. 74. 
tetapi berpegang pada keyakinan bahwa prosedur-prosedur dan institusi-institusi demokrasi merupakan cara paling tepat untuk mengatur kehidupan. kolektif, dan jika dukungan bagi alternatif-alternatif anti sistem sangat kecil atau kurang lebih terisolasi dari kekuatan-kekuatan pro demokrasi. ${ }^{19}$

Juan J. Linz dan Alfred Stepan berpendapat bahwa untuk memperkuat konsolidasi demokrasi sebagaimana paparan di atas, setidaknya terdapat lima syarat, yang saling berkaitan agar demokrasi dapat kokoh terkonsolidasi. ${ }^{20}$ Pertama, ada masyarakat sipil. Kedua, harus ada masyarakat politik yang relatif otonom. Syarat pertama dan kedua yakni, ${ }^{21}$ harus dapat saling melengkapi. Masyarakat sipil yang kuat, dengan kemampuan untuk menghasilkan alternatif-alternatif politik dan untuk memantau pemerintah dan negara dapat membantu memulai transisi, membantu melawan pembalikan-pembalikan,membantu mendorong terselesaikannya transisi, dan membantu konsolidasi serta memperdalam demokrasi. Oleh karena itu, pada setiap tahap proses demokratisasi, sangatlah dibutuhkan masyarakat sipil yang hidup dan mandiri.

Ketiga, Pemerintahan berdasarkan hukum. Semua tokoh penting harus dituntut untuk bertanggung jawab pada, dan dibiasakan dengan, pemerintahan yang berdasarkan hukum. Sebuah negara hukum sangat dibutuhkan bagi konsolidasi demokrasi, karena merupakan cara paling penting yang didalamnya pemerintahan terpilih dan administrasi negara tunduk pada jaringan hukum, pengadilan, serta norma-norma masyarakat sipil yang bukan hanya mengendalikan kecenderungan negara yang tidak sah, melainkan juga menanamkannya di dalam suatu jaringan mekanisme yang saling berkaitan yang membutuhkan keterbukaan dan pertangungjawaban.

Keempat, Birokrasi yang bermanfaat. Pada negara demokrasi, pemerintahan harus mampu menjamin dan melindungi hak-hak warga negara dan memberikan pelayanan dasar lainnya yang dituntut warga negara tersebut, pemerintahan yang demokratis harus mampu menjalankan secara efektif monopoli kekuasaan sah yang dimilikinya. Untuk itu, negara memerlukan birokrasi yang dianggap bermanfaat oleh pemerintah demokrasi yang baru.

Kelima, Masyarakat ekonomi. Hal ini berkaitan dengan ekonomi, dimana terdapat suatu norma, institusi dan aturan yang disusun dengan memperhatikan segi-segi sosial politik, dan dapat diterima, yang menjadi perantara antara negara dan pasar.

: Juan J. Linz, et. al. Op. Cit. HIm. 40-41.

islbid. HIm. 41-49.

'Masyarakat sipil adalah kelompok-kelompok, gerakan-gerakan, dan upaya-upaya individual yang diorganisasi sendiri serta relatif otonom berusaha untuk menyuarakan nilai-nilai, mendirikan perkumpulan, dan menggalang solidaritas serta memperjuangkan kepentingan mereka. Sedangkan masyarakat politik adaiah tokoh-tokoh politik yang bersaing mendapatkan hak yang sah untuk menjalankan kontrol atas kekuasan publik dan aparat negara. 


\section{Posisi Korban Pelanggaran HAM}

Kajian hukum dalam kaitannya dengan korban berkaitan dengan pertanyaan dasar: Apakah ada kejahatan (pelanggaran hukum pidana); Siapa pelakunya; Siapa yang menderita kerugian oleh suatu kejahatan;'Apa kerugiannya; dan Bagaimana kerugian tersebut dipulihkan.

Konsep kejahatan dan siapa yang menjadi korban kejahatan adalah pangkal tolak untuk menjelaskan bagaimana posisi korban. Ada dua konsep kejahatan. Pertama, kejahatan dipahami sebagai pelanggaran terhadap negara atau kepentingan publik yang direpresentasikan oleh instrumen demokratik negara. Kedua, kejahatan dipahami sebagai pelanggaran terhadap kepentingan orang perseorangan dan juga melanggar kepentingan masyarakat, negara, yang esensinya melanggar kepentingan pelakunya sendiri. Konsep yang pertama dilandasi oleh pemikiran yang berbasis pada konsep keadilan retributif (retributive justice) dan konsep kedua dilandasi konsep keadilan restoratif (restorative justice).

Konsep pertama memberikan landasan pemikiran bahwa kepentingan yang dilanggar adalah kepentingan publik atau negara, sehingga dapat ditarik suatu konklusi bahwa negaralah yang dirugikan, apabila terjadi suatu kejahatan atau pelanggaran hukum pidana. Konsep ini dibangun, menurut sejarahnya, adalah untuk menghindari tindakan balas dendam dari orang perseorangan. ${ }^{22}$ Negara dan orang yang disangka melanggar hukum pidana menjadi pusat perhatian dalam penyelenggaraan peradilan pidana. ${ }^{23} \mathrm{Negara}$ memperoleh legitimasinya sebagai wakil sah dari representasi kepentingan publik dan basis pelampiasan balas dendam personal yang bersifat emosional dan subjektif, selanjutnya direkonstruksi dalam penyelenggaraan peradilan pidana sebagai rasionalisasi atau objektivikasi balas dendam kepada pelanggar hukum pidana. ${ }^{24}$

Posisi korban kejahatan, yakni negara, dalam sistem peradilan memainkan peranan sentral dan dominan dalam mengambil keputusan terhadap tersangka atau pelanggar hukum pidana. Sebaliknya, pihak lainnya yang tidak dikonsep sebagai yang terlibat atau tercakup', sebagai pelaku atau korban, diposisikan sebagai instrumen pembuktian dalam proses pidana, yakni sebagai saksi. Sebagai salah satu alat bukti, saksi tidak mempunyai hubungan hukum dengan perkara

${ }^{22} \mathrm{Pada}$ mulanya individu yang menjadi korban berperan aktif dalam peradilan, dimana sekarang masih ditemukan dalam peradilan tradisional. Seiring dengan perkembangan organisasi negara modern. dan dikombinasikan dengan tujuan-tujuan sosial lainnya, menjadikan negara memainkan peran dominan.

${ }^{23}$ Irvin Waller. 1986. "Victima vc Regina vs Malefactor: Justice for The Next 100 Year" dalam J.M. van Dijk. edt.Criminal Law in Action: An Overview of Current Issue in Western Societies, Arheim: Gaouda Qunt. Hilm. 422.

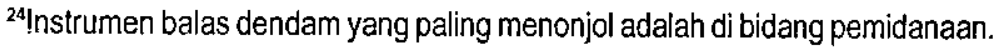


pelanggaran hukum pidana yang disaksikan, yang selanjutnya dijadikan instrumen dalam penjatuhan pidana.

Konsep tersebut dominan hingga akhir abad kesembilan belas. Konsep kejahatan melanggar negara mulai digugat dan dinilai tidak sesuai dengan kenyataan hidup seharihari. Fiksi atau anggapan bahwa negara menjadi korban tunggal tersebut sulit diterima dalam situasi nyata dan objektif. ${ }^{25} \mathrm{Negara}$ dan sistem peradilannya tidak dapat berdiri sebagai wakil khayalan bagi orang yang nyata secara personal telah menderita karena korban kejahatan. Dosa pelanggar adalah bukan entitas abstrak yang diakui negara, tetapi korbannya, komunitas aktual, dan nyata. ${ }^{26}$

Konsep kejahatan menurut konsep keadilan restoratif diberi pengertian yang lebih nyata. Kejahatan adalah konflik antar orang perseorangan. Kejahatan dipahami sebagai pelanggaran, pertama dan terutama melanggar hak perseorangan dan melanggar hak masyarakat (kepentingan publik), kepentingan negara, dan secara tidak langsung melanggar kepentingan pelanggar. ${ }^{27}$ Korban kejahatan adalah orang yang dirugikan karena pelanggaran hukum pidana (kejahatan), pertama dan terutama orang yang langsung menderita karena kejahatan disebut korban sesungguhnya (primer), kemudian disebut korban, sedangkan yang lainnya sebagai korban tidak langsung (sekunder).

Sistem peradilan pidana sebagai sistem penyelesaian konflik di tempat mana korban, masyarakat, negara dan pelanggar melakukan mediasi' untuk menyelesaikan konflik karena adanya pelanggaran hukum pidana (kejahatan). Negara tidak lagi diposisikan sebagai peran tunggal dan dominan dalam penyelenggaraan peradilan pidana, karena negara bukanlah korban tunggal yang sesungguhnya dan perannya dibatasi dan lebih diperankan fungsinya sebagai mediator dan fasilitator. ${ }^{28}$ Hubungan antara pelanggar dan korban dalam proses peradilan dibangun berdasarkan hubungan dialogis, yang dikenal dengan hubungan antar manusia yang saling membutuhkan (humanisasi). Fokusnya adalah dampak yang ditimbulkan oleh kejahatan dan instrumen peradilan pidana difungsikan untuk maksud tersebut.

Pelanggaran HAM selalu membawa korban, suatu penegakan hukum terhadap

${ }^{25}$ Viktimologi mempunyai peran signifikan dalam mempengaruhi konsep kejahatan dan korban kejahatan dalam arti nyata dan objektif melalui kajian empirik. Perkembangan 1960-an dan 1970-an berkonsentrasi pada kejahatan dan penjahat pada pengkajian kembali penyelenggaraan sistem peradilan pidana dari perspektif korban dalam rangka memperoleh kembali kerugian yang diderita dan mengembalikan hak-haknya. Tema sentralnya adalah restitusi dan kompensasi.

${ }^{25}$ John O Haley. 1996. "Crime Prevention through Restorative Justice: Lessons from Japan", dalam Joe Hudson dan Burt Galaway, edt. Restorative Justice. Illonois: Charles C. Thomas Publisher. HIm. 349-372.

${ }^{2}$ Kepentingan pelanggar juga terlanggar karena perbuatannya sendiri, sehingga membuat keharmonısan hubungannya dengan masyarakat terganggu.

${ }^{28}$ Daniel W van Ness. 1996. "Restorative Justice and International Human Right." Dalam Joe Hudson dan Burt Galaway, edt. Restorative Justice. Illonois: Charles C. Thomas Publisher. Him. 234. 
pelanggaran HAM tanpa memperhatikan kepentingan korban akan selalu membawa luka yang tidak akan pernah sembuh dan pada akhirnya akan selalu menimbulkan pertentangan-pertentangan dalam kehidupan bernegara. Persoalan terbesar yang dihadapi bangsa Indonesia saat ini adalah terlalu banyak kasus pelanggaran HAM yang telah memasuki masa daluwarsa untuk dapat dilakukan pengusutan dan pemeriksaan di tingkat pengadilan. Kasus seputar $\mathrm{G} 30$ S/PKI, Kasus Tanjung Priok dan beberapa Kasus di Aceh, tidak dapat diselesaikan melalui mekanisme peradilan biasa.

Peradilan HAM yang dibuat oleh pemerintah bersama DPR untuk memberikan peluang dapat diadilinya kasus-kasus pelanggaran HAM di masa lalu; tetap memunculkan persoalan, karena pelaku pelanggaran HAM merasa menjadi korban dari upaya penegakan hukum, sehingga pada akhirnya persoalan pelanggaran HAM menjadi penghambat kemajuan berdemokrasi di Indonesia akibat tidak dapat diobatinya luka-luka yang dirasakan oleh korban pelanggaran HAM dan luka pelaku pelanggaran HAM yang merasa dikorbankan.

Salah satu upaya yang dapat ditempuh dengan melihat pengalaman penyelesaian pelanggaran HAM di negara-negara lain, seperti Afrika Selatan, yaitu dalam bentuk
Komisi Kebenaran dan Rekonsiliasi (Truth and Reconciliation Commission) yang diharapkan dapat menyelesaikan secara komprehensif kasus-kasus pelanggaran HAM masa silam. Komisi ini akan mengumpulkan semua kebenaran, melakukan penyembuhan lukaluka masa lalu (healing process), memberi rehabilitasi dan kompensasi bagi para korban. Amnesti menjadi bagian dari pertimbangan yang akan diberikan oleh Komisi Kebenaran dan Rekonsiliasi. Disamping itu korban pelanggaran HAM akan memperoleh pemulihan nama baik, pemulihan keseimbangan batin dan pemberian ganti rugi.

Patut disayangkan, Rancangan Undangundang tentang Komisi Kebenaran dan Rekonsiliasi sebagai bagian yang diamanatkan Undang-undang Peradilan HAM belum selesai disusun. Untuk itu, perlu kiranya memperhatikan instrumen-instrumen internasional maupun pengalaman negara lain dalam penyelesaian pelanggaran HAM yang berat, khususnya mengenai korban pelanggaran HAM. Pengadilan HAM harus mengatur apa yang dinamakan principles relating to reparation berkenan dengan korban yang meliputi restitusi, kompensasi dan rehabilitasi, dengan berpedoman kepada United Nations Declaration of Basic Principles of Justice for Victims of Crime and Abuse of Power 1995. ${ }^{29}$

2"Muladi. 2000. "Prospek Pengaturan Pengadilan Hak Asasi Manusia (HAM) di Indonesia di Masa.Depan." Makalah. Hlm. 16. 


\section{Penyelesaian Kasus Pelanggaran HAM}

Pelanggaran HAM berat masa lalu di Indoneisa sebagai bagian dari penguasa otoriter banyak yang tidak diselesaikan secara adil oleh sistem yang ada, sehingga menjadi bom waktu atau menjadi duri yang menghalangi upaya perbaikan menuju tatanan yang lebih demokratis. Padahal, sudah tersedia banyak instrumen yang dapat dirujuk dan difungsikan sebagai mekanisme untuk menyelesaikan masalah, baik pada tingkat internasional ${ }^{30}$ maupun secara nasional. ${ }^{31}$

Kelembagaan yang ada, misalnya badanbadan pengadilan, komisi-komisi nasional, badan-badan pemerintahan maupun organisasi-organisasi non pemerintah, merupakan mekanisme-mekanisme yang dapat diaktifkan untuk bekerja memajukan dan melindungi HAM. Upaya penyelesaian dapat dilakukan melalui dua jalur yaitu jalur pengadilan atau jalur rekonsiliasi (Komisi Kebenaran dan Rekonsiliasi). Kedua mekanisme ini memiliki kekuatan dan kelemahan. Dengan demikian, upaya pengintegrasian perlu dikaji secara mendalam dan utuh, sehingga menghasilkan pola penyelesaian kasus pelanggaran HAM berat masa lalu secara baik. ${ }^{32}$
Pendekatan melalui Komisi Kebenaran dan Rekonsiliasi yang menghasilkan pengakuan atas pelanggaran HAM oleh pelaku yang disusul dengan permohonan maaf dipandang merupakan langkah yang paling akomodatif terhadap perasaan keadilan para korban dan diharapkan dapat memulihkan keseimbangan sosial dan memelihara persatuan dan kesatuan nasionai. Pengakuan tentang adanya pelanggaran HAM berat di masa lampau dipandang merupakan salah satu cara yang ksatria dan dapat mengatasi konflik yang berkepanjangan antara pelaku dan korban atau keluarga korban, selanjutnya negara dapat memberikan amnesti kepada pelaku pelanggaran HAM berat.

Namun demikian, suatu amnesti dapat memiliki pengaruh negatif dalam penyelesalan pelanggaran HAM berat: ${ }^{33}$ Pertama, Dengan amnesti, korban pelanggaran HAM berat masa lalu tidak memiliki hak lagi untuk melakukan penuntutan, sehingga amnesti dipandang sebagai hak prerogatif dari negara dan peran korban telah diambil alih oleh negara. Dalam kasus pelanggaran HAM berat konsep amnesti harus dikaji ulang, sehingga amnesti tidak saja merupakan hak dan tanggung jawab negara, tetapi juga merupakan hak dari para korban.

20Misalnya Statuta Roma, UDHR, ICCPR, ICESCR.

3'TAP MPR XVII Tahun 1998, TAP MPR V Tahun 2000, Undang-Undang Nomor 39 Tahun 1999 tentang HAM. Undang-Undang Nomor 26 Tahun 2000 tentang Pengadilan HAM.

${ }^{32}$ Subtansi dari Undang-Undang Nomor 26 Tahun 2000 tentang Pengadilan HAM memuat tentang keterkartan antara Komisi Kebenaran dan Rekonsiliasi.

${ }^{33}$ Romli Atmasasmita. 2001. Reformasi Hukum, Hak Asasi Manusia dan Penegakan Hukum. Bandung: Mandar Maịu. Hlm. 183. 
Kedua, Amnesti yang diberikan oleh Kepala Negara telah menempatkan para korban pelanggaran HAM berat sebagai warga negara kelas dua di hadapan hukum yang tidak memiliki hak untuk membela diri. Ketiga, Ongkos sosial dan politik pemberian amnesti oleh negara tanpa mempertimbangkan hakhak korban sangat tinggi dibandingkan dengan sebaliknya. Dalam konteks ini, konsep amnesti khusus untuk penyelesaian kasus-kasus pelanggaran HAM berat perlu dikembangkan dalam konteks hukum Indonesia. Keempat, Pemberian Amnesti oleh Negara terhadap pelaku pelanggaran HAM berat mengandung makna merendahkan harkat dan martabat para korban pelanggaran HAM berat, sehingga metode tersebut sudah tidak relevan lagi dengan kàrakteristik dan kualitas pelanggaran HAM berat itu sendiri.

Untuk itu, pemberian amnesti harus selektif. Komisi Kebenaran dan Rekonsiliasi harus memastikan bahwa pertanggungjawaban tidak dikorbankan. Orang-orang yang bertanggungjawab terhadap pelanggaran HAM berat jangan sampai terlindungi atau mendapatkan impunity. Komisi Kebenaran dan Rekonsiliasi berfokus pada reparasi dan retorasi. Komisi ini berupaya untuk: ${ }^{34}$ Pertama, Menyusun catatan yang dapat dipercaya tentang kekerasan yang terjadi. Kedua, Mengakui rasa sakit dari para korban, menempatkan cerita kekerasan tersebut dalam suatu platform dan mencari, selanjutnya mendapatkan kompensasi bagi penderitaan para korban. Ketiga, Membuat rekomendasi untuk melaksanakan pembaruan kelembagaan untuk mengindari pengulangan kejahatan itu. Keempat, Menyediakan suatu tindakan pertanggungjawaban dengan cara mengidentifikasikan lembaga-lembaga atau individu-individu yang bertanggungjawab.

Penyelesaian pelanggaran HAM yang berat melalui mekanisme peradilan dengan tujuan untuk menghukum pelaku pelanggaran HAM yang berat sekaligus mengembalikan harkat dan martabat korban pelanggaran HAM berat. Namun, terdapat pro dan kontra terhadap konsep penghukuman ini bagi pelaku pelanggaran HAM berat, khususnya berkaitan dengan masalah penghukuman sebagai salah satu konsekuensi hukum dan pelanggaran HAM berat.

Bagi mereka yang pro terhadap konsep penghukuman terhadap pelaku pelanggaran HAM berat, alasan yang dikemukakan adalah: ${ }^{35}$ Pertama, Penghukuman dapat memelihara keadilan bagi korban (retributive justice). Kedua, Penghukuman mengandung arti memperkuat legitimasi pemerintahan transisi. Ketiga, Penghukuman mencegah terjadinya pelanggaran HAM berat di masa yang akan datang. Prinsip the criminals should go unpunished akan tetap dijaga. Keempat, Penghukuman menghilangkan impunity dari para pelaku pelanggaran HAM berat dalam konteks hubungan antara superior dan subordinat.

${ }^{34} \mathrm{Alan}$ Tieger. 2000. "Transitional Justice dan Kejahatan terhadap Kemanusiaan." Lokakarya Nasional VI Hak Asasi Manusia. Surabaya: Universitas Surabaya. 21-24 Nopember. HIm. 4-5.

${ }^{35}$ Romli Atmasasmita. Op. Cit. Hlm. 184. 
Alasan yang dikemukakan pihak yang kontra terhadap konsep penghukuman terhadap pelaku pelanggaran HAM berat adalah: ${ }^{35}$ Pertama, Penghukuman hanya akan meningkatkan perasaan dendam korban yang bertujuan pembalasan dan tidak akan menciptakan keadilan. Kedua, Penghukuman hanya akàn menciptakan distorsi sosial yang berkepanjangan dan korban baru dari konflik horisontal dar vertikal. Ketiga; Penghukuman kurang relevan dengan pelanggaran HAM yang berat karena dalam kasus tersebut muatan politik lebih besar dan bukan sematamatä hanya persoalan legalistik. Keempat, Penghukuman tidak menciptakan suatu restorative justice.

\section{Simpulan}

Tidak ada rumusan yang mudah untuk menghasilkan demokratisasi bagi negaranegara yang keluar dari praktek kenegaraan yang otoriter. terutama apabila menghadapi upaya penanggulangan kejahatan terhadap kemanusian atau pelanggaran HAM berat. Perbedaan cıri-ciri dasar proses transisi, tahapan-tahapan transisi dan hakikat dari kejahatan masa lampau dalam sejarah akan menentukan ketepatan pendekatan yang diambil.

Meskipur, demikian, ada beberapa cara agar dapat renyelesaikan kejahatan HAM berat di masa silam. Pertama, harus ada komitmen bermakna berupa kehendak dan sumber-sumb $=r$ daya dari pihak pemerintah. Disamping meningkatkan upaya investigasi dan pengusutan serta penuntutan yang diperlukan bagi pelanggaran HAM berat. Kedua, harus ada partisipasi masyarakat untuk turut mengupayakan penyelesaian yang adil dengan memperhatikan hak-hak korban pelanggaran HAM berat. Penyelesaian pelanggaran HAM berat di masa lalu dilakukan dengan transparan, sehingga sumber hidup dari benih-benih demokratisasi akan berkembang seiring dengan ditegakannya hukum melalui mekanisme hukum yang menjunjung tinggi kepastian hukum dengan bersandar pada keadilan. ב

\section{Daftar Pustaka}

Alan Tieger."Transitional Justice dan Kejahatan terhadap Kemanusiaan." Lokakarya Nasional VI Hak Asasi Manusia, Surabaya: Universitas Surabaya. 21-24 Nopember 2000.

C. de Rover. 2000. To Serve \& To Protect: Acuan Universal Penegakan HAM. Jakarta: Rajawali Press.

Daniel $W$ van Ness. "Restorative Justice and International Human Right." Dalam Joe Hudson dan Burt Galaway, edt. 1996.

Restorative Justice, Illonois: Charles

C. Thomas Publisher.

Ifdal Kasim, Editor. 2001. Hak Sipil dan Politik: Esai-esai Pilihan Buku 1. Jakarta: ELSAM.

Irvin Waller. "Victima vc Regina vs Malefactor: Justice for The Next 100 Year," dalam J.M. van Dijk, edt. 1986. Criminal Law

30/bid. 
in Action: An Overview of. Current Issue in Western Societies. Arheim: Gaouda Quint.

John O Haley. "Crime Prevention through Restorative Justice: Lessons from Japan." dalam Joe Hudson dan Burt Galaway, edt.1996. Restorative Justice, Illonois: Charles C. Thomas Publisher.

Juan J. Linz, et. al. 2001. Menjauhi Demokrasi Kaum Penjahat: Belajar dari Kekeliruan Negara-Negara Lain. Jakarta: LIPI.

Komisi Nasional Hak Asasi Manusia. 2001. Keadilan dalam Masa Transisi. Jakarta: KOMNASHAM.

Margaret A. Schuler dan Dorothy Q. Thomas, Penyunting. 2001. Hak Asasi Manusia Kaum Perempuan: Langkah demi Langkah. Jakarta: LBH APIK.
Muladi. 1997.Hak Asasi Manusia, Politik dan Sistem Peradilan Pidana. Semarang: BP UNDIP.

- "Prospek Pengaturan Pengadilan Hak Asasi Manusia (HAM di Indonesia di Masa Depan)." Makalah. 2000.

Rhoda E. Howard. 2000. HAM: Penjelajahan Dalil Relativisme Budaya. Jakarta: Grafiti Press.

Romli Atmasasmita. 2001. Reformasi Hukum, Hak Asasi Manusia dan Penegakan Hukum. Bandung: Mandar Maju.

Vratislav Pechota. "Konvenan Hak Sipil dan Politik: Sejarah dan Perkembangannya", dalam Ifdhal Kasim, Editor. 2001. Hak Sipil dan Politik: Esai-esai Pilihan Buku 1. Jakarta: ELSAM. 